\title{
The impact of forest fire on air-quality and visibility in Palangka Raya
}

\author{
Sumaryati $^{1}$, Nani Cholianawati ${ }^{2}$, and Asri Indrawati ${ }^{3}$ \\ ${ }^{1,2,3}$ Center for Atmospheric Science and Technology, The National Institute of Aronautic and \\ Space \\ ${ }^{1}$ sumaryati@lapan.go.id, sumary.bdg@gmail.com
}

Received 26 January 2019, Revised 2 March 2019, Published 29 March 2019

\begin{abstract}
It has been analyzed impact of forest fire on the air quality using PM10 parameter and visibility during 2000 - 2014 in Palangka Raya, Central Kalimantan province. Palangka Raya is an affected forest fire area with a monsoonal rainfall type which has one peak of the rainy season in January and one peak of the dry season in August. Drought condition has an impact on rising forest fire intensity causes increasing of PM10 concentration and decresing of visibility in July to November moreover when there is an El Niño phenomenon. The result of PM10 analysis shows that the air quality index in Palangka Raya during December - June is in a good level category and still below the ambient air quality standard with an average concentration of $19 \mu \mathrm{g} / \mathrm{m} 3$. The impact of forest fire on declining air quality due to increasing of PM10 concentration occurred in July November with an average concentration rising of $129 \mu \mathrm{g} / \mathrm{m} 3$. The El Niño phenomenon rises the PM10 concentration due to increasing of forest fires, but the increasing of PM10 is not comparable to the strength of El Niño, because of combustion condition and and human activities that play a role in forest fires. The worst impact of El Niño occurred in 2002, although the El Niño strength was only moderate, which is a half the time from July to November Palangka Raya covered air quality with dangerous levels with PM10 concentrations of more than $\mu \mathrm{g} / \mathrm{m} 3$. A high PM10 concentration environment reduces the visibility significantly, which is visibility in the no fire condition about $8 \mathrm{~km}$, but when the huge forest fire the visibility drops to $0.1 \mathrm{~km}$.
\end{abstract}

Keywords: forest fire, PM10, air quality, visibility

\section{Introduction}

Forest fire has a bad impact on the environment, health, ecology, and economic losses, but this event always occurs repeatedly in Indonesia, especially Kalimantan and Sumatra. The intensity of forest fire is influenced by economic factors such as the economic crisis, the price of logs, CPO exports, the Ministry of Forestry's budget and supported by natural factors especially dry weather during El Niño years (Cahyono et al, 2015). Based on the rainfall study conducted by Tjasyono (1999) most of Central 
Kalimantan has an equatorial rainfall type, but the next studies conducted by Aldrian and BMKG for most of the region has monsoonal rainfall type (Aldrian and Susanto, 2003). Areas with equatorial rainfall types are characterized by a bimodal monthly rainfall distribution with two maximum and minimum rainfall peaks, and the maximum rainfall peak coinciding by the equinox period. The monsoonal rainfall type has a monthly rainfall distribution with one peak of the rainy season and the dry season respectively, with a maximum peak in December/ January and a minimum in July/ August. This type of rainfall determines when periods of forest fires occur frequently.

One of the important forest fire emissions is particulate which often forms haze. Particulates are grouped according to aerodynamic diameter dimensions, such as PM10, PM05, PM2.5, and PM1. PM10 is a particulate that has an aerodynamic diameter of less than $10 \mu \mathrm{m}$, aerodynamic diameter of PM05 is less than $5 \mu \mathrm{m}$, and so on. Particulate removes of the atmosphere through washing by rainwater and deposites due to gravity settling or an object such as a plant. Some plant specieses have a good ability to deposite particulate for reducing particulate in urban ambient air (Viecco et al, 2018). The smaller the particle size the greater the viscosity force so that it becomes more difficult to settle in the ground.

The study of particulate is important because of its impact on the health and atmospheric environment. Suspended particulate in the air is inhaled into the respiratory system, the smaller of the particulate size is more dangerous on health impact because of its penetration in the respiratory system more deeper (Zannaria et al, 2009, Kim et al, 2015). Particulate with aerodynamic diameter more than $10 \mu \mathrm{m}$ can be filtered in the nose and upper throat system, while PM10 can enter the respiratory system and even

enter the bloodstream (Anderson, 2012). Particulate is scattering light, thereby reducing the visibility that is disturbs the safety of transportation, especially air transportation. The reduced visibility due to forest fires is a serious problem in Tjilik Riwut air port, Palangka Raya even flight activities are stopped.

The complexity impact of forest fire, both on ecology and economy has been widely publicized. A bibliometric study conducted by Juárez-Orozco et al (2017) shows that Kalimantan and the El Niño incident are locations and phenomena that are widely studied in relation to forest fires. In this paper, it is investigated how the change of PM10 concentration during forest fires, especially in the El Niño event, on air quality whether it is still safe or it becomes harmful to health. The standar to assess air quality criteria is the ISPU (Indeks Standar Pencemar Udara, air pollutant standard index) and ambient air quality standards. It also saw how the impact of PM10 on reduced visibility that disrupts transportation safety.

\section{Method}

Air quality parameters in this study was PM10. PM10 measurement was carried out by the Environmental Agency of Palangka Raya City using the air quality monitoring system (AQMS) in the Tjilik Riwut Airport area, Palangka Raya. To find out weather factors that influence the intensity of forest fires by El Niño and La Nina events, it was assesesd the Oceanic Niño Index (ONI) issued by NOAA and dounlowded on the 
website https://www.esrl.noaa.gov/psd/ data/correlation/oni.data. The greater of positive ONI value meant the stronger of El Niño event and vice versa the greater of negative ONI value it was mean the stronger of la Nina event.

Air quality was analyzed using ISPU (Indeks Standar Pencemar Udara, air quality standard index) criteria established and formulated in the Decree of the Head of Bapedal number 107 in 1997. The ISPU values at each concentration level was formulated by equation (1) and ISPU criteria seen in Table 1. The second air quality analysis was based on ambient air quality standards listed in the attachment of Government Regulation number 41 in 1999, that the ambient air quality standard for PM10 was measured for 24 hours or a daily average was $150 \mu \mathrm{g} / \mathrm{m}^{3}$.

$$
I_{x}=\frac{\left(I_{a}-I_{b}\right)}{\left(X_{a}-X_{b}\right)}\left(X_{x}-X_{b}\right)+I_{b}
$$

Where Ix was ISPU related to concentration of $\mathrm{x}(\mathrm{Xx}) . \mathrm{I}_{\mathrm{a}}$ and $\mathrm{I}_{\mathrm{b}}$ were the upper limit and lower limit concentrations, while $\mathrm{Xa}$ and $\mathrm{Xb}$ were the upper limit and lower limit concentrations showed in Table 1

Table 1. Correlation between ISPU and PM10 and its criteria

\begin{tabular}{ccccc}
\hline No & $\begin{array}{c}\text { PM10 daily } \\
\text { concentration PM10 } \\
\left(\mu \mathrm{g} / \mathrm{m}^{3} \mathrm{jam}\right)\end{array}$ & ISPU & Colour code & Criteria \\
\hline 1 & 50 & 50 & green & Good \\
2 & 150 & 100 & Blue & Moderate \\
3 & 350 & 200 & Yelow & Unhealthy \\
4 & 420 & 300 & Red & Very unhealthy \\
5 & 500 & 400 & Black & Dangerous \\
6 & 600 & 500 & Balck & Dangerous \\
\hline
\end{tabular}

One of the effects of particulates from forest fires on the atmospheric environment was reduced the visibility. Daily average visibility data starting at 15:00 WIB simultaneously with ISPU was downloaded at https://www.ogimet.com/gsynres.phtml.en, on the location of Tjilik Riwut Airport. Regarding to the WMO definition (World Meteorological Organization), visibility was the distance needed to reduce by $5 \%$ the intensity of the light emitted by incandescent lamps at a temperature of $2700 \mathrm{~K}$ measured at an altitude of $2.5 \mathrm{~m}$ above ground.

\section{Results and Discussion}

The main content of biomass is a carbon element with a composition between $45 \%$ to $50 \%$ depending on the type and part of biomass (Suhui et al, 2018). The carbon element is one of the important elements in PM10 from forest fires. Samson et al (2012) research showed that particulates from biomass burning contain a lot of carbon and a small portion of potassium and calcium. 
The amount of biomass burning and combustion conditions determine the amount of PM10 emissions. Perfect combustion conditions due to sufficient oxygen supply causes the carbon element to become $\mathrm{CO}_{2}$, otherwise lack of oxygen supply is formed into $\mathrm{CO}$, hydrocarbons, and particles in the smoke. Perfect combustion is characterized by a flaming phase and imperfect combustion is characterized by a smoldering phase. The study of peatland burning in the flaming phase with sufficient oxygen supply produced a lot of $\mathrm{CO}_{2}$, which means it produced less smoke and the opposite condition when the smoldering phase was due to lack of oxygen supply (Lim et al, 2019). From various biomass combustion conditions, $1-7 \%$ of the total biomass that is burned is formed into smoke, and smoke consists of water vapor and particulates including PM10 (Samson et al, 2012).

Palangka Raya as the capital of Central Kalimantan province, the quality of the air is strongly influenced by forest fires. One of the air quality parameters is PM10. The average daily PM10 concentration in Palangka Raya in time series based on ISPU criteria is shown in Figure 1.a and to distinguish the effect of forest fires is made on a separate scale Figure 1.b. Based on PM10 data, it can be estimated the effect of Palangka Raya forest fires. The effect of forest fires is seen from July to November in an annual cycle. The monthly PM10 concentration forms a peak with a high concentration in August/ September. High PM10 concentrations indicate the highest peak intensity of forest fires. The peak of this forest fire occurs at the end of the dry season, when the biomass is very dry, according to the type of monsoonal rainfall according to BMKG and Aldrian where the peak of the dry season occurs around August (Aldrian and Susanto, 2003). 


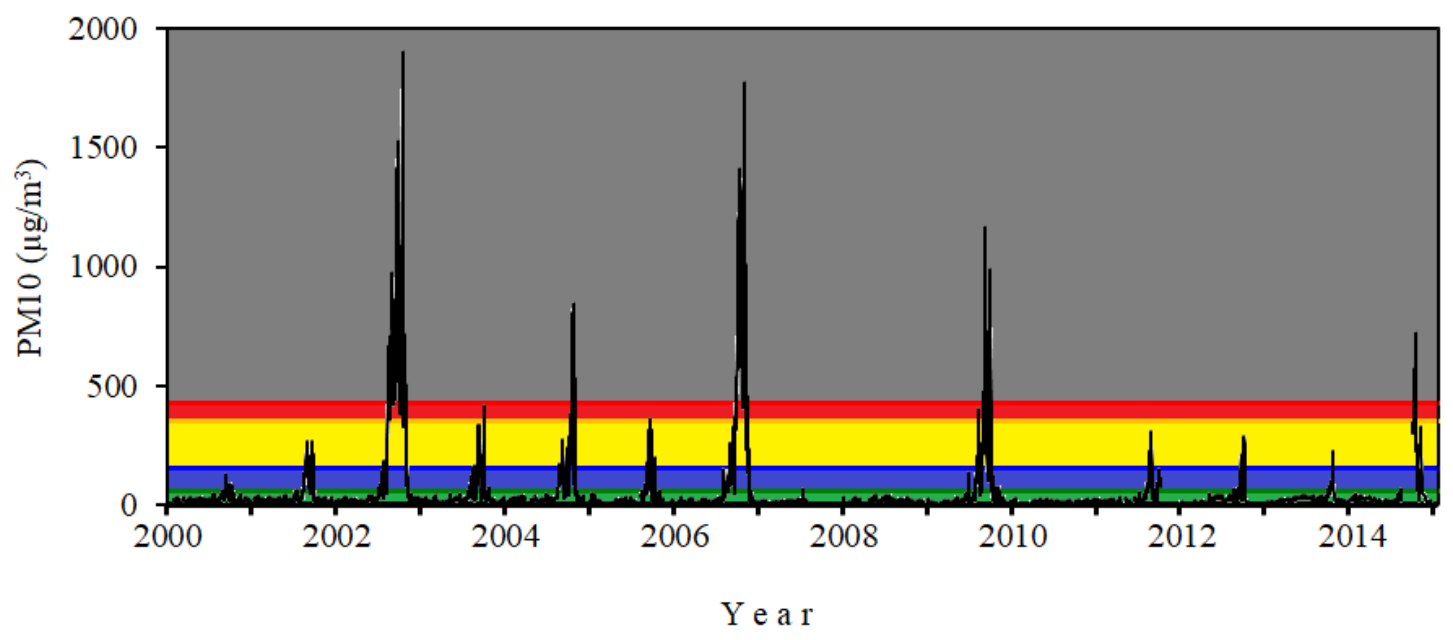

(a)

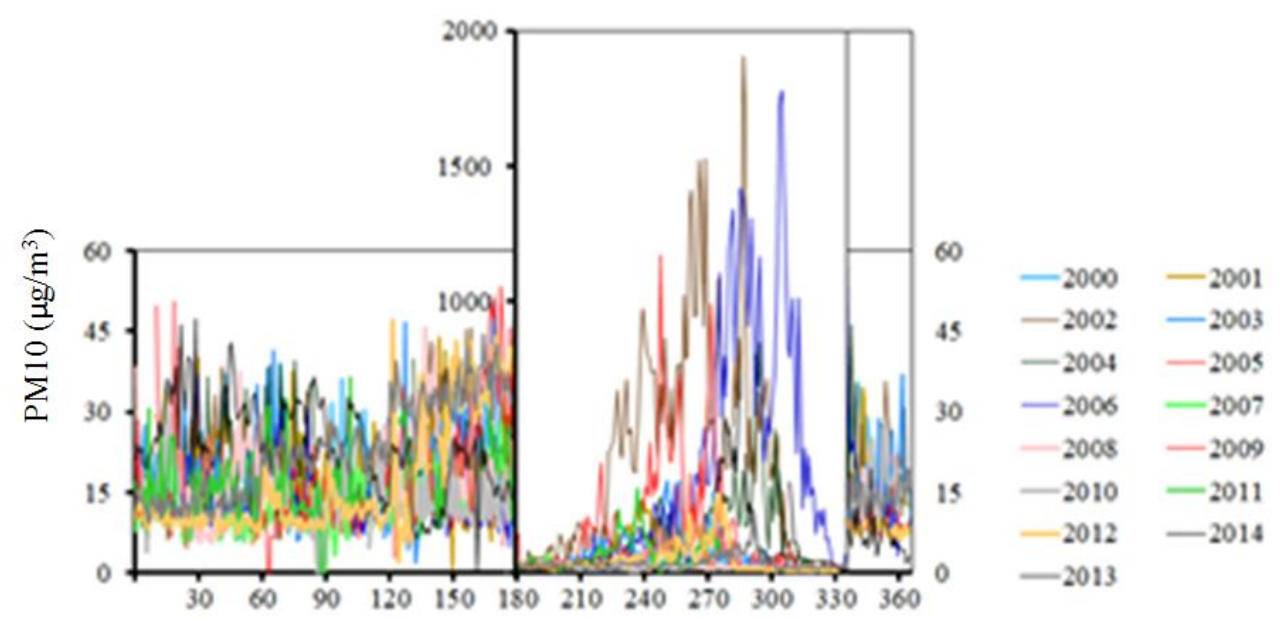

Julian day

(b)

Figure 1. PM10 concentrations in time series (a) and monthly variations each year (b)

El Niño and La Nina impact assessments have been carried out both in Indonesia and other countries, both related to drought and high rainfall, and to the intensity of forest fires (Yuliyanti and Hayasaka, 2013, Yocom et al, 2010). The impact of El Niño in Indonesia is the dry season longer than normal conditions. The opposite phenomenon is La Nina that is a rainy season with a longer duration and more total rainfall. NOAA (National Oceanic and Atmospheric Administration) identifies the weakness of the El Niño and La Nina phenomena with the Oceanic Niño Index (ONI). The ONI value is calculated based on sea surface temperature in the East Pacific region at coordinates $\left(5^{\circ} \mathrm{N}-5^{\circ} \mathrm{S}, 170^{\circ}-120^{\circ} \mathrm{W}\right)$ called the nino area 3.4. ONI values from $2000-2014$ and criteria for the strengths of the El Niño and La Nina phenomena are presented in Figure 2. 


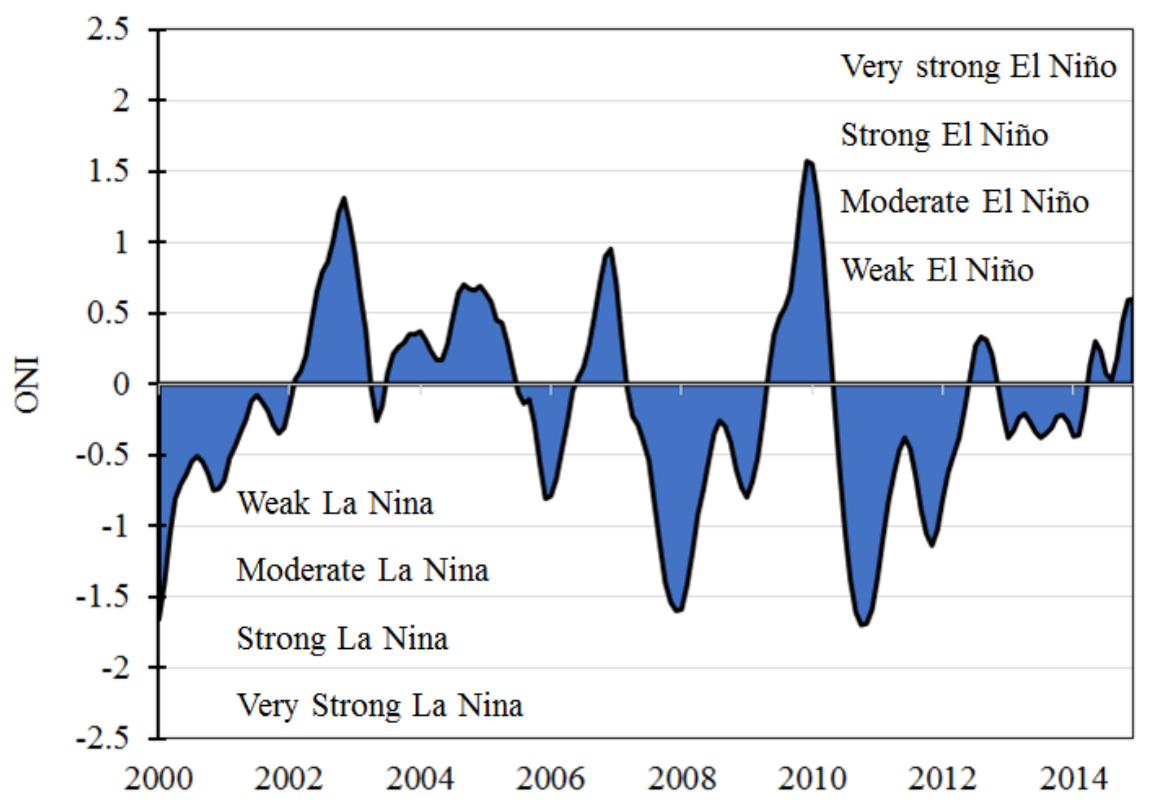

Figure 2. ONI value from 2000 until 2014

The amount of burned biomass material can be indicated by the large concentration of PM10 in the atmosphere strongly influenced by the El Niño and La Nina phenomena. When the El Niño phenomenon occurred, namely in 2002, 2004, 2006, 2009, and 2014 the concentration of PM10 was very high and the air quality based on ISPU from the PM10 parameter reached the worst conditions reaching danger level. During normal conditions, there is no El Niño or La Nina phenomenon, i.e. in 2001, 2003, 2012 and 2013, air quality worst levels reached unhealthy. At the time of La Nina in 2000, 2007, 2008, and 2010 the worst condition of air quality based on ISPU from PM10 remained at a good level, except in 2000 which was at a moderate level. Whereas in 2005 and 2011, despite the phenomenon of weak La Nina, the worst air quality reached unhealthy levels.

When La Nina is weak in 2005 and 2001, PM10 concentrations were quite high. The burning of biomass forest that is forced on the La Nina incident tends to produce a lot of smoke in which there is PM10 because of relatively wetter biomass conditions. In El Nino 2002, 2004, and 2009, the highest ONI value recorded in 2009, but the concentration of PM10 experienced the highest in 2002. This shows that there are other factors besides the weather, namely human activity that determines the magnitude of forest fires (Cahyono, 2015). This human activity can worsen air quality through land clearing by burning, or vice versa through prevention activities against forest fires..

As a forest fire risk area, PM10 concentrations in Palangka Raya are strongly affected by forest fires. In December to June, the average PM10 concentration was 19 $\mu \mathrm{g} / \mathrm{m}^{3}$, while in July to November which is a period of forest fires, the concentration of PM10 increase to $129 \mu \mathrm{g} / \mathrm{m}^{3}$. Based on ISPU Indonesia's criteria, when there were no forest fires, from December to June, the air quality in Palangka Raya on the PM10 pollutant element was still in good criteria with a green symbol (Figure 1). When 
compared with ambient air quality standards, when there is no forest fire, PM10 pollutant quality is still far below the ambient air quality standard.

2002: Moderate EI Niño

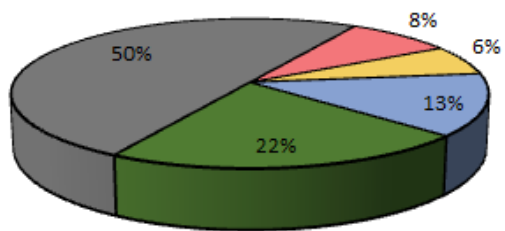

(a)
2006: Weak El Niño

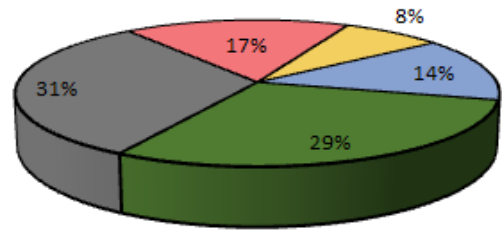

(b)

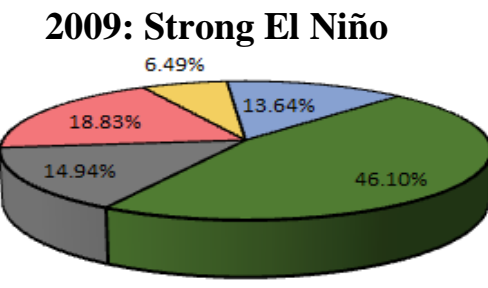

(c)

Figure 3. Percentage of ISPU during July-November of El Niño 2002, 2006 and 2009 (green: good, blue: moderate, yellow: unhealthy, red: very unhealthy, black: danger)

During July to November which is categorized as a period of fire, air quality dropped to the lowest level. Air quality dropped to hazard levels far above ambient air quality standards, even the highest concentrations reached $1900 \mu \mathrm{g} / \mathrm{m}^{3}$ in 2002 and $1800 \mu \mathrm{g} /$ $\mathrm{m}^{3}$ in 2006 . The percentage of air quality during fires that coincided with El Nino events is presented in Figure 3.

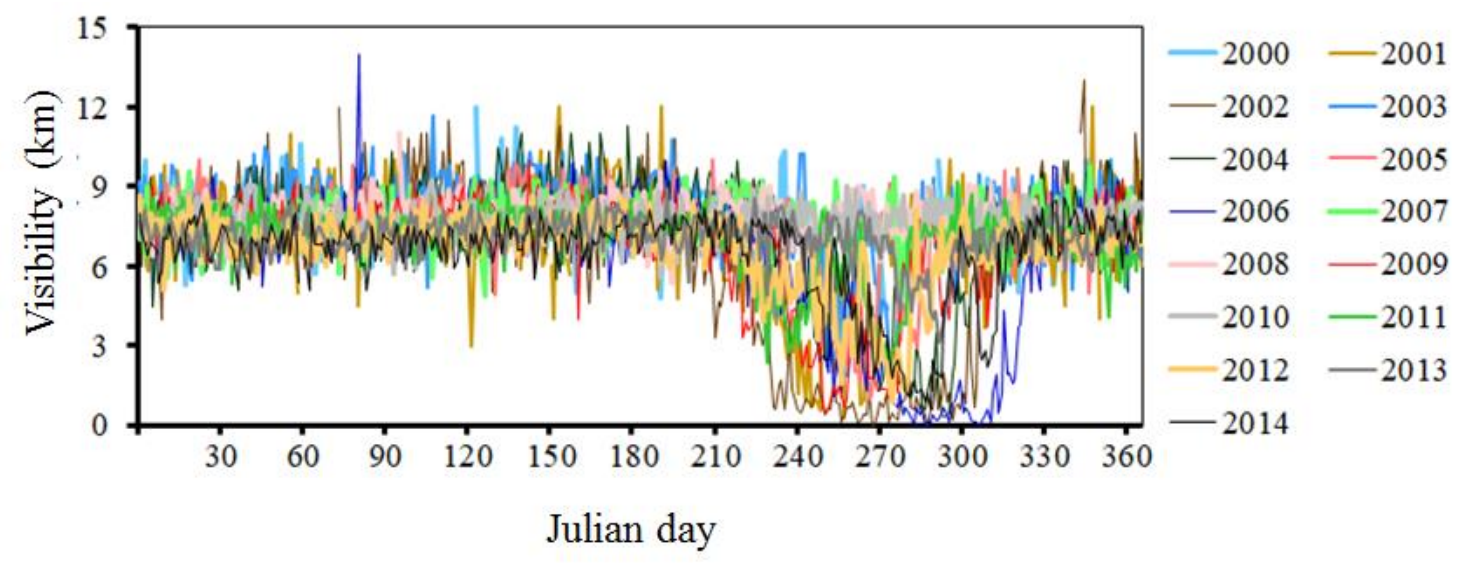

Figure 4. Visibility in Palangka Raya

In certain regions, air quality characteristics are at a good level for a long time, but in certain periods they can experience a drastic decline to danger levels such as that which occurs in Palangka Raya, potentially causing acute disease. But because of the occurrence of air quality in this 'danger' level recurring so potentially cause chronic disease. The impact of acute diseases in areas prone to forest fires is more commonly suffered by women in the age range of 18-60 years with complaints of cold cough (Awaludin, 2016). A more in-depth study of the impact of particulates from forest fires in addition to respiratory symptoms such as coughing, asthma, colds as well as their chronic effects on heart vessel disorders (Black et al, 2017, Finlay et al, 2012).

The reduction in the intensity of light by particulates which results in reduced visibility follows the following Beer-Lambert law: 


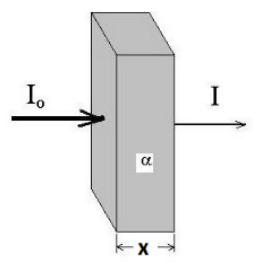

$$
I_{x}=I_{0} e^{-\alpha x}
$$

Where $\mathrm{I}_{0}$ is the intensity of the light before entering the media, $\mathrm{I}_{\mathrm{x}}$ is the intensity of the light after entering the atmospheric media as thick as $\mathrm{x}$, and $\alpha$ is the coefficient of light absorption in the atmospheric media, in this case PM10 is reviewed. Visibility is the distance $x$ when the light intensity decreases by $5 \%$. So equation (2) the amount of visibility ( $\mathrm{x}$ ) can be written as follows

$$
x=\frac{0,0223}{\alpha}
$$

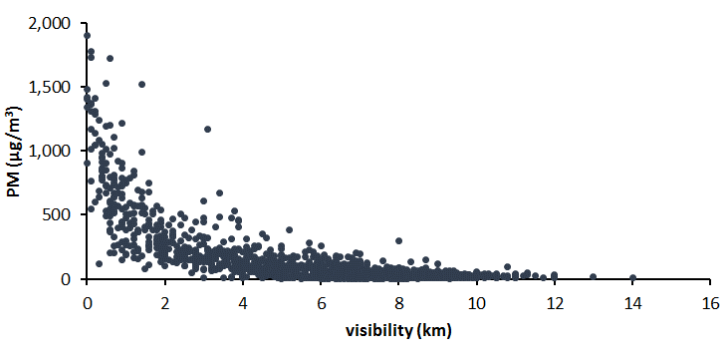

(a)

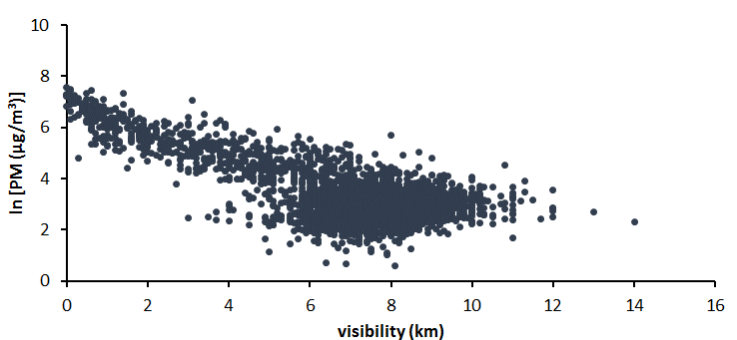

(b)

Figure 5. Plot scatter between visibility and PM10 concentration (a). Normal scale, (b). Logarithmic scale

Based on Figure 5, we can see that there is a significant reduction in visibility of PM10 when its concentration increases. Studies conducted in urban areas in Beijing show the effect of PM2.5 on reduced visibility divided into two groups, namely in clean air conditions with concentrations of PM2.5 $<100 \mathrm{mg} / \mathrm{m}^{3}$, increasing PM2.5 concentrations decreases visibility linearly, but for high PM2.5 conditions, visibility decrease tends to be exponential (Wang, et al. 2019). The correlation between PM10 concentration and visibility (Figure 5a) in Palangka Raya which is an area affected by forest fires tends to form an exponential function. However, the scatter plot on a logarithmic scale for PM10 (Figure 5.b), shows that the exponential function is only at high PM10 concentrations above $50 \mathrm{mg} / \mathrm{m}^{3}$.

The reduced visibility is affected by air pollutants, especially particulates and meteorological conditions. Many researches have studied relating to the relationship between atmospheric composition and visibility (Founda et al., 2016; Cao et al., 2012). The study explained that visibility is greatly influenced by size, chemical composition and also concentration of particles in the air (Singh, et al 2017). Sulfate and carbon concentrations contained in particulates are the main contributors in contributing to decreased visibility (Malm, 1999). In addition to several meteorological factors that affect visibility such as humidity, temperature and wind speed (Chung-Yih Kuo et al, 
2013), the height of the planetary boundary layer also influences the concentration of particulates in the atmosphere which in turn affects visibility. According to research conducted by $\mathrm{Qu}$, et al (2017), low PBL heights often occur when conditions are low wind speeds and high humidity, which will cause high concentrations of particulates in the air and low visibility.

Because many factors affect visibility, and the review in this study only involved PM10, the effect of PM10 was clearly seen when the concentration was high, i.e. above $50 \mu \mathrm{g} / \mathrm{m}^{3}$. In conditions of PM10 concentrations below $50 \mu \mathrm{g} / \mathrm{m}^{3}$, many other factors are meteorological conditions and other pollutants whose significance appears to reduce visibility. Therefore, an increase in PM10 concentration under conditions of concentrations of less than $50 \mu \mathrm{g} / \mathrm{m}^{3}$ appears to reduce visibility.

\section{Conclussion}

Weather condition determines the intensity of forest fires as indicated by the PM10 concentration. There is an increase in PM10 concentration when el Niño occurred, as well as a decrease in concentration in La Nina year, however the increase and decrease is not proportional to the ONI value which indicates the strength of the El Nino and La Nina phenomena. The background condition according to national air quality index, the air quality in Palangka Raya is at a good level with the concentration still far below the ambient air quality standard. Disturbance of forest fires causes air quality to drop to dangerous levels and concentrations far above ambient air quality standards. The high concentration of PM10 during forest fires reduces visibility from the initial condition of about $7.7 \mathrm{~km}$ to $6.4 \mathrm{~km}$, and the worst condition of visibility is only $0.1 \mathrm{~km}$.

\section{Aknowlegdment}

This research is funded by The Center for Atmospheric Research and Technology, The National Institute of Aeronautics and Space. We also thank to head of Palangka Raya Environmental Agency for supporting PM10 data, Ogimet for supporting visibility data, and NOAA for supporting ONI data.

\section{References}

Aldrian E dan R.D Susanto (2003). Identification of Three dominant Rainfall Regions within Indonesia and relationship to Sea Surface Temperature. International Journal of Climatology. 23: 1435-1452

Anderson J.O., J. G Thundiyil, dan Andrew Stolbach. 2012. Clearing the Air: A Review of the Effects of Particulate Matter Air Pollution on Human Health. J. Med Toxicol, 8(2): 166-175

Awaludin (2016).Keluhan Kesehatan Masyarakat Akibat Kabut Asap Kebakaran Hutan dan Lahan. Journal Endurance 1(1): 37-46

Black, C., Tesfaigzi, Y., Bassein, J. A., \& Miller, L. A. (2017). Wildfire smoke exposure and human health: Significant gaps in research for a growing public health issue. Environmental toxicology and pharmacology, 55, 186-195. 
doi:10.1016/j.etap.2017.08.022

Cahyono A.A., S.P. Warsito, A. Andayani, D.H. Darwanto (2015). Faktor-faktor yang Mempengaruhi Kebakaran Hutan di Indonesia dan Implikasi Kebijakan. Jurnal Sylvia Lestari. Vol. 3 No. 12015 (103-112)

Cao, J.-j., Wang, Q.-y., Chow, J. C., Watson, J. G., Tie, X.-x., Shen, Z.-X., Wang, P., and An, Z. (2012) Impacts of aerosol compositions on visibility impairment in Xi'an, China, Atmos. Environ., 59, 559-566

Chung-Yih Kuo, Fang-Ching Cheng, Shih-yu Chang, Chuan-Yao Lin, Charles C.K. Chou, Chung-hung Chou and Yan-Ruel Lin. (2013). Analysis the Major Factors Affecting the Visibiloity degradation in two Stations, Journal of the Air \& Waste Management Association, 63:4, 433-441, DOI: 10.1080/10962247.20120762813

Finlay, S. E., Moffat, A., Gazzard, R., Baker, D., \& Murray, V. (2012). Health impacts of wildfires. PLoS currents, 4, e4f959951cce2c. doi:10.1371/4f959951cce2c

Founda, D., Kazadzis, S., Mihalopoulos, N., Gerasopoulos, E.,Lianou, M., and Raptis, P. I. (2016) Long-term visibility variation in Athens (1931-2013): a proxy for local and regional atmospheric aerosol loads, Atmos. Chem. Phys., 16, 11219 11236, doi:10.5194/acp-16-11219-2016

Juárez-Orozco S.M., C. Siebe, dan D. Fernández y Fernández (2017). Causes and Effects of Forest Fires in Tropical Rainforest: A Bibliometric Approach. Journal SAGE Pub. Tropical consevation Science, Vol 10: 1-14

Kim K-H, E. Kabir, dan S Kabir (2015). A Review on the Human Health Impact of Airborne Particulate Matter. Science Direct, Elsevier. https://www.sciencedirect.com/science/article/pii/S0160412014002992

Lin S., P. Sun, and Xinyang Huang (2019) Can Peat Soil Support a Flaming Wildfire? Journal of International Association of Wildland Fire Vol 28(8)

Malm W.C (1999) Introduction to Visibility, Colorado State University.

Qu Y., Y. Han, Y. Wu, P. Gao, and T. Wang (2017) Study of PBLH and Its Correlation with Particulate Matter from One-Year Observation over Nanjing, Southeat China. Remote Sens., 9, 668 doi: 10.3390/rs9070668

Samsono Y.N., V.A. Ivanov, D.J. McRae dan S.P. Baker (2012). Chemical an Dispresal Characyeristics of Particulate Emissions from Forest Fire in Siberia. International Journal of Wildland Fire, http://dx.doi.org/10.1071/WF11038

Singh A., W.J. Bloss, and F.D. Pope (2017) 60 Years of UK Visibility Measurements: Impact of Meteorology and Atmospheric Pollutants on Visibiliy. Atmos. Chem. Phys., 17, 2085-2101

Suhui Ma, Feng He, DI Tan D. Zou, Z. Yan, Y. Yang, T Zhou, K. Huang, H. Shen, and J. Fang (2018). Variations and Determinants of Carbon Content in Plants: a Global Synthesis, Biogeosciences, 15, 693-702

Tjasyono, B. (1999). Klimatologi Umum. Bandung: ITB 
Viecco M., S. Vera, H. Jorquera, W. Bustamante, J. Gironas, C Dobbs, and E. Leiva (2018) Potential of Particle Matter Dry Deposition on Green Roofs and Living Walls Vegerattion for Mitigating Urban Atmospheric Pollutio in Semiarid Climates. Sustainability, 10, 2431, doi: 10.3390/ su10072431

Wang X, R. Zhang, and W. Yu. 2019. The Effects of PM2.5 Concentration and Relative Humidity on Atmospheric Visibility in Beijing, JGR Atmosphere, Vol. 124 (4): 2235-2259

Yocom L.L., P.Z. Fule, P.M Brown, J. Cerano, J. Villanueva-Diaz, D.D Falk, dan E. Cornejo-Oviedo (2010). El Niño Southern Oscillation Effect on Regime in Northeasthern Mexico has Changed over Time. Ecology Jun;91(6):1660-71

Yuliyanti N. dan H. Hayasaka (2013). Recent Active Fires under El Niño Condition in Kalimantan Indonesia, American Journal of Plant Science, 4, 685-696

Zannaria N.D., D Roosmini, M Santosa (2009). Karakteristik Kimia Paparan Partikulat Terespirasi. Jurnal Sains dan Teknologi Nuklir Indonesia, IX, No 1: 37-50 